\title{
Research on the Impact of Electronic Commerce on Trade English Correspondence Writing
}

\author{
Longyuan $\mathrm{XiaO}^{1, \text { a }}$ \\ ${ }^{1}$ Jiangxi College of Foreign Studies, Jiangxi Province, Nanchang, 330099 \\ 54892713@163.com
}

Keywords: Electronic Commerce, Trade English Correspondence Writing

\begin{abstract}
The rapid development of electronic commerce on trade English Correspondence had a profound impact, opportunities for employees and presented a huge challenge. E-commerce has become a trend in contemporary international trade development. As e-commerce era of international business major communication tool, Business English Correspondence only to follow the basic principles, but also through the appropriate use of communication to achieve success in international business negotiations aim to expand trade opportunities and promote the development of international trade.
\end{abstract}

\section{Introduction}

All transactions are dependent on the exchange of information, particularly in the international exchange in the modern age of electronic commerce, the exchange of information is especially important. Business English Correspondence English letter refers to the process of interaction in foreign trade exchange of information, telegraph, telex, fax and e-mail. Replaced by new and efficient means of communication with the development of science and technology, some of the old means of communication such as the telegraph and telex has basically been faxes and e-mail.

Foreign Correspondence English usage throughout all aspects of e-business, from establishing business relationships with new clients to the final closing of the transaction, good correspondence transaction can proceed smoothly, and if improper wording perceptibly, affecting both sides of the normal transmission of information and communication, even make the relationship breakdown. Then write Business English Correspondence should pay attention to what the problem?

\section{The impact of electronic commerce on international trade}

E-commerce refers to the different transactions subject transactions and payment settlement via the Internet platform and delivery of goods through the logistics, the completion of a commercial activity transactions, which are generally considered to be a community of electronic data exchange and online trading as the main content business model. For our businesses, e-commerce trading platform not only means, it also provides a fast and convenient channel for China's most enterprises access to the global market. Currently, there are three main e-commerce model: B2B, B2C and C2C. E-commerce has revolutionized the traditional face to face with the entity transaction mode, various business platforms around the world have come alive, such as eBay, Alibaba, Global market.

Due to historical and economic development and other factors, States' international e-commerce business development shows imbalance, but its a good development trend. Current research on international trade and e-commerce are concentrated in a combination of two aspects, one is to explore the impact of electronic commerce on international trade, as well as coping strategies, the second is to explore e-commerce logistics services for international trade opportunities and shocks and their coping strategies. Joe Yang, who pointed out that the application of EDI technology simplifies the trading process, improve the trade efficiency, make foreign trade enterprise management methods and revolutionized the way government regulation; e-commerce to expand the scope of trade body to promote trade in services and technology trade development of. TEENAGER believes that the operating environment of e-commerce, competition between enterprises is not the past that a simple competitive products and services, but a higher level of 
e-commerce business model and business between the industrial chain competition. Juan suggested that cross-border e-commerce logistics industry is undergoing a new revolution, taking into account cost, speed, security, and even includes more content aftermarket logistics services came into being. Thus, e-commerce is a positive impact on all aspects of international trade, but at the same time to the practice of international trade presented a huge challenge.

\section{The Business English Correspondence Study Overview}

Domestic scholars past 10 years foreign trade English Correspondence, mostly concentrated in three areas. First, the style or discourse analysis of foreign trade English Correspondence, respectively, from the grammatical features such as SURVEYING AND, discourse features and lexical features three analyzes the stylistic features of correspondence English; the second is the foreign trade English Correspondence language characteristics and the method of translation research, such as Li Haiyan, Liu Zhen Long and other advocates of the "faithful", "smooth" as the style of translation standards; three is the study of the relevant correspondence teaching, such as Zhou Qiming, Xuan Hui Ping vocabulary by teaching proved to effectively block Approach improve students' writing achievement of Foreign Trade Correspondence to be able to use these in writing prefabricated language is more accurate, more fluent expression of ideas. Business English Correspondence belong hot topic in business English studies; and from academic researchers to your field of view, economics and education scholars pay more attention to business English than linguistics. Although the results of previous research a lot, but in terms of depth and innovation is still insufficient. Therefore, subsequent to Foreign Trade Correspondence study theoretical level, innovative fusion aspect interdisciplinary, comparative research fuss.

The fourth is facing with changing of evaluate new ideas. Existing index system of academic assessment measures classified assessment did not take. Upgraded after private colleges and universities have to re-adjust design schools and the development of ideas based on these evaluation index. Such self-examination pass rate by the external quality evaluation standard of education into a fully independent evaluation conducted by the school, that is controlled by an external evaluation criteria to give priority to internal control primarily by his law oriented to self-discipline based.

\section{The Business English Correspondence function in e-commerce}

Currently more popular in foreign trade foreign trade clerk positions, freight forwarders, business translation, declaration, Dan Zhengyuan, foreign trade manager, Merchandiser, international business negotiations personnel. Foreign employees in basic skills is the use of Business English Correspondence to communicate with customers or related parties; and with the development of e-commerce, many online businesses are resolved, rather than through traditional paper documents. Content Business English Correspondence become an important basis for solving these problems, the importance of foreign trade English Correspondence visible. Business English Correspondence in International Trade as an integral part, plays a positive role in the international trade.

First, the international trade in foreign trade English Correspondence included locutionary act, illocutionary act and perlocutionary act, Foreign Trade English Correspondence discourse necessarily have an impact on people's income letter thoughts, feelings, attitudes and behaviors. Thus, one important function is to deal with foreign trade English Correspondence affairs.

Secondly, the international trade is the exchange of activities between different countries and regions of goods and services. Due to the time difference, geographic location, and other factors, different cultural backgrounds, the international trade business of the parties can not do everything instant communication, foreign trade English Correspondence therefore becomes the main tool they share feelings, to obtain and impart information. Business English Correspondence in International Trade, to maximize reduce costs, improve efficiency, so that they deal effectively communicate and exchange information. 
Once again, foreign trade English correspondence is the basis of international trade practices. Modern international trade also known as "trade documents." Business English Correspondence in all aspects of international trade throughout the process, from establishing business relationship to offer, the transaction, and then shipped claims complaints, mostly through communication correspondence to solve. Content Business English Correspondence is contracted, single-system basis and claims and other matters, all aspects of the correspondence dealings constitute an important legal basis, especially in the event of disputes.

\section{Characteristics of Foreign Trade English Correspondence}

Category Business English Correspondence belong to business English, it refers to letters operators in the international trade in used, telegraph, telex, fax and e-mail. It is the main international trade business contact information, basic and important communication tool but also for international trade practice, which has the following main features.

Legal Features. International trade process is very complex, many links between wide covers. If a part of problem, it will affect the normal conduct of the whole transaction, and may lead to a lawsuit. Parties involved in international trade come from different countries, different cultural environment, leading to international trade exhibits complicated features. Therefore, the international trade-related legal action or dispute more complicated. Foreign Trade English Correspondence with a certain force of law in international trade business, of course, subject to the relevant law. Content of Foreign Trade English Correspondence involved should abide by international conventions and national laws are not contrary to the principles of the relevant parties lies. For example, in actual business, although the inquiry is not legally binding, but after the conclusion of the contract, the contents of inquiry become an integral part of the consultation document; if a dispute arises, inquiries can be treated as a basis for the dispute. As another example, an offer is legally binding. Once accepted an offer by the disc, the offeror may have to offer to the conditions and deal with the other party to perform the contract (the offer) obligations.

In international trade language support. The main role of Business English Correspondence is passed through the relevant language in international trade activities transaction information between the two sides. Stylistic Features of Business English Correspondence summed up mainly: clear and correct, the content specific and informative, lively, comprehensive understanding, a clear answer to the other party or the other requirements explicitly requested.

In the context of international trade knowledge. The main background in foreign trade English Correspondence is involved in international trade practices, the contents of the entire process around foreign trade activities and expand. Skilled practitioners to use professional knowledge and Foreign languages, communication with relevant parties in all aspects of international trade practices

Intercultural Communication features. Business English Correspondence fundamental role is to achieve intercultural communication, and transaction objects from different cultural backgrounds to communicate. Therefore, effective trade English Correspondence than mere verbal communication, but also the employees have the ability to cross-cultural communication.

Transmission route diversity. With the development of science and technology and information technology, communication and speed of information dissemination dramatically. With the development of electronic commerce, letters and telegrams of transmission, etc. In addition to traditional mail, telex and facsimile, there are many other ways to communicate in a timely manner, etc., which trade practitioners raised new challenges

\section{The impact of electronic commerce on trade English Correspondence Writing}

First, to be clear and concise format

Business English Correspondence generally includes a header, write the date, inside address, salutation, several major portion of the body, at the end of courtesy, signature, etc., can also be cut or add some content depending on the circumstances. Letter format can also be reduced with the 
personal preferences line (that is, each row address within the letter and the body begins to indent each have the same number of cells), flat head type (each row is aligned from the left edge) or a mixed formula ( That is part of the inside address and other required branch with flat head type, each letter of the text began indent number of squares). But generally prefer foreign topless, because this form can print efficiency, the appearance of the letter looks neater. It was even slightly increase the gap when printing between paragraphs to make the paragraph clearer, let the reader at a glance, from the senses to experience pleasure.

Second, the content should be concise

Correspondence theme should be made straight, without a list of some of the tedious courtesy, writing a lot of people feel not beat around the bush cut to the chase. Brief is to use as little as possible and the exact meaning of words to express their views. Avoid long-winded, repeated and lengthy phrases. Try to use short sentences instead of more than 40 or 50-word sentence, usually 20-25 words to make sentences easier to understand the recipient. I have seen just trade a college graduate with a full A4 page printed a letter correspondence hope to establish business links with each other. One can imagine that customers such as letters and telegrams to see such a big turnoff will happen, if they would want a company with such a long-winded to continue to contact you?

Third, the language must be standardized polite

Famous British scholar Leach (Leech) has proposed politeness principle that politeness is the norm when dealing with interpersonal relationships known. He politeness divided into six categories:

(A) policy guidelines. It refers to the reduction in the instruction and commitments detrimental to the others' point of view: as little as possible so that others damaged; let others benefit as much as possible.

(B), generous guidelines. It refers to the reduction of self-interest in the instruction and commitments perspectives: as little as possible to make their own benefit; make yourself suffer as much.

(C), praised the guidelines. It refers to the reduction of others in derogatory expressions and statements.

(D), modesty guidelines. It refers to the reduction in the expression and representation in their praise: praise themselves as little as possible; as much belittle yourself.

(E), the consistency of the guidelines. It refers to the reduction in the statements and inconsistencies in the views of others: to minimize their differences; to maximize consistency between the two sides. Sympathy guidelines. It refers to the reduction in the expression of an emotional confrontation with each other: to minimize resentment against each other; try to increase sympathy for each other.

These principles center is the cooperation and courtesy, so it has special significance for Business Correspondence English. Because people have to face, if not in the letter to the other party to stay face, could well deal will lose the sale; courtesy of Business English Letters attached to each other's point of view, respect each other's rights, aspirations and needs, to meet each other's psychology, It can produce a pleasant feeling, thus contributing to and expanding foreign trade. So we not only pay attention to the use of standardized language, but also pay attention to the application of the principles of politeness.

\section{Conclusion}

With globalization progresses, the widespread popularity of electronic commerce, the increasingly fierce competition in international trade; tact and courteous Business English letters will create a respect each other, seek the cooperation of the atmosphere so that the other party willing to cooperate with us, soIt helps us to remain invincible in the competition. 


\section{References}

[1] R.X. Zeng. Local Universities restructuring and development practice and policy research report. Tianjin Vocational and Technical Normal College, 5(2007) 46-47.

[2] C.Li. Reflections on the construction of experiment teaching demonstration center of new private undergraduate colleges. Shandong Foreign Language Teaching. 11(2006) 26-30.

[3] C.Y.Wang. How to raise the confidence of private undergraduate students. Vocational and Technical Education. 9 (2011) 56-58.

[4] J.X.Li.Transformation development of local universities: path selection and connotation construction. Vocational and Technical Education .9(2009) 19-22.

[5] Y.X.Zhang. Cooperative condition and performance evaluation of local colleges. Shaoxing University. 4(2007) 129-132. 